\title{
KOMPETENSI PENGADILAN AGAMA \\ DALAM PENYELESAIAN SENGKETA PERBANKAN SYARIAH \\ BERDASARKAN UNDANG-UNDANG NOMOR 3 TAHUN 2006 \\ DI HUBUNGKAN DENGAN PENYELESAIAN SENGKETA \\ PERBANKAN SYARIAH PASCA PUTUSAN \\ MAHKAMAH KONSTITUSI NOMOR 93/PUU-X/2012 ${ }^{1}$
}

\author{
Oleh : Moh. Sutoro \\ Dosen Fakultas Ekonomi Universitas Pamulang \\ Email: mohamad.sutoro@gmail.com
}

\begin{abstract}
Abstrak
Tahun 2006 dipandang tahun yang paling revolusioner dalam sejarah eksistensi peradilan agama dalam tata hukum Indonesia. Pelimpahan kewenangan memeriksa, memutus, dan menyelesaikan perkara ekonomi syariah kepada Peradilan Agama memberi isyarat pengakuan akan eksistensi peradilan agama sekaligus sebagai perwujudan bagi keinginan sebagian, bahkan seluruh umat Islam Indonesia untuk menyelesaikan sengketanya sesuai tuntunan syariat. Namun dalam praktiknya Sebelum adanya judicial reviewe Undang-Undang Nomor 21 Tahun 2008 tentang Perbankan syariah yang dalam praktiknya mengandung ketidakpastian hukum karena adanya persoalan yang bermula dari perbedaan penafsiran dalam menentukan forum mana yang memiliki kewenangan untuk menyelesaikan sengketa perbankan syariah yang sedang dihadapinya yaitu adanya Choice of Forum dan adanya Choice of law yang pada akhirnya rumusan tersebut menimbulkan adanya ketidakpastian hukum.
\end{abstract}

Kata Kunci :Kompetensi, Penyelesaian Sengketa, kepastian hukum

\begin{abstract}
The year 2006 is seen in the most revolutionary in the history of the existence of religious courts in the Indonesian legal system. Delegation of authority to examine, decide and resolve syariah economic case to the Religious Court signaled recognition of the existence of religious courts as well as the realization of the desire of the majority, even all Muslims in Indonesia to resolve the dispute in accordance guidance Shari'a. However, in practice before the judicial reviewe Act No. 21 of 2008 concerning Islamic banking, which in practice contains legal uncertainty because of the problem stems from differences in interpretation in deciding which forum has the authority to resolve disputes Islamic banking at hand that is the Choice of Forum and the Choice of law which in turn raises the formulation of legal uncertainty.
\end{abstract}

Keywords: Competence, Dispute Resolution, legal certainty

\section{A. Pendahuluan}

Keberadaan lembaga Peradilan Agama di Indonesia tidak dapat dilepaskan dari

\footnotetext{
${ }^{1}$ Naskah diterima tanggal 17 Juni 2016, direvisi: 27 Juni 2015, disetujui untuk terbit 1 Juli 2016 dalam Volume 3 No. 1 Juli 2016
} 
kebutuhan masyarakat Indonesia yang beragama Islam dalam melaksanakan ajaran agamanya yang berupa hukum Islam. Secara yuridis Peradilan Agama sebagai salah satu pelaksana kekuasaan kehakiman di Indonesia telah diatur oleh konstitusi yakni dalam Pasal 24 Ayat (2) UUD NRI 1945 yang menyebutkan bahwa : "Kekuasaan kehakiman dilakukan oleh sebuah Mahkamah Agung dan badan peradilan yang berada di bawahnya dalam lingkungan Peradilan Umum, lingkungan Peradilan Agama, lingkungan Peradilan Militer, lingkungan Peradilan Tata Usaha Negara, dan oleh sebuah Mahkamah Konstitusi.”

Eksistensi lembaga Peradilan Agama sebagai salah satu pelaksana kekuasaan kehakiman di Indonesia mengalami pasang surut sejalan dengan situasi politik pemerintahan yang ada. Sebelumnya, berdasarkan ketentuan Pasal 49 Ayat (1) Undang Undang Nomor 7 Tahun 1989, kewenangan Peradilan Agama hanya terbatas pada penyelesaian sengketa di bidang perkawinan, kewarisan, wasiat, dan hibah yang dilakukan berdasarkan hukum Islam, serta wakaf dan shadaqoh.

Namun setelah dilakukannya amandemen, berdasarkan Undang - Undang Nomor 3 Tahun 2006 Tentang Perubahan Atas Undang - Undang Nomor 7 Tahun 1989 Tentang Peradilan Agama, Pengadilan Agama telah memiliki suatu kompetensi baru khususnya dalam menangani sengketa ekonomi syariah. Dalam Pasal 49 menyatakan bahwa, Pengadilan Agama bertugas dan berwenang memeriksa, memutus dan menyelesaikan perkara di tingkat pertama antara orang - orang yang beragama Islam di bidang perkawinan, waris, wasiat, hibah, wakaf, zakat, infaq, shadaqoh dan ekonomi syariah.

Lahirnya Undang - Undang Nomor 21 Tahun 2008 Tentang Perbankan Syariah kemudian diharapkan selain mampu membawa dampak positif pada eksistensi lembaga perbankan syariah di Indonesia tapi juga diharapakan dapat memperkuat legitimasi kewenangan baru Pengadilan Agama yakni dalam hal penyelesaian sengketa ekonomi syariah. Namun, pada kenyataannya harus diakui bahwa UU Perbankan Syariah justru malah membawa dampak negatif terhadap kewenangan Pengadilan Agama sebab, telah menimbulkan adanya tumpang tindih kewenangan antara Pengadilan Agama dan Pengadilan Negeri sehingga menimbulkan pula ketidakpastian hukum akibat adanya tumpang tindih kewenangan tersebut.

Sebelum adanya judicial review Undang-Undang Nomor 21 Tahun 2008 tentang 
Perbankan syariah yang dalam praktiknya mengandung ketidakpastian hukum karena adanya Choice of Forum dan adanya Choice of law dan menghilangkan hak konstitusional nasabah dalam menyelesaikan sengketa perbankan syariah. Setiap orang tentunya ingin mendapatkan keamanan dan kenyamanan dalam setiap sendi kehidupannya. Apalagi dalam hal yang berkaitan dengan dunia perbankan. Setiap kesepakatan dan transaksi antara para pihak, sudah semestinya mendapat jaminan kepastian hukum yang jelas dan tegas.

Namun apa jadinya bila kepastian hukum tersebut absen dan malah menambah masalah dengan aturan yang tidak jelas. Dalam hal ini, kepastian hukum tak hanya diartikan adanya aturan, namun lebih dari itu, yakni adanya aturan yang menyelesaikan masalah, bukan memunculkan persoalan baru. jika suatu undang-undang mempersilakan untuk memilih lembaga peradilan mana yang menyelesaikan sengketa, akan menimbulkan berbagai penafsiran dari berbagai pihak. "Dengan adanya kontradiktif tersebut antara yang satu dengan yang lainnya lahirlah penafsiran sendirisendiri sehingga makna kepastian hukum menjadi tidak ada” .

Persoalan bermula dari perbedaan penafsiran dalam menentukan forum mana yang memiliki kewenangan untuk menyelesaikan sengketa perbankan syariah yang sedang dihadapinya. Di mana memang terdapat beberapa alternatif forum untuk menyelesaikan sengketa perbankan syariah mulai dari di luar pengadilan (non litigasi) hingga litigasi Adalah Pasal 55 ayat (1), (2), dan (3) Undang-Undang Nomor 21 Tahun 2008 tentang Perbankan Syariah (UU Perbankan Syariah) yang telah memunculkan persoalan tersebut. Pada prinsipnya, pertentangan terjadi antara rumusan Pasal 55 ayat (1) yang menyatakan bahwa penyelesaian sengketa Perbankan Syariah dilakukan oleh pengadilan dalam lingkungan Peradilan Agama, sedangkan dalam Pasal 55 Ayat (2) menyatakan, para pihak yang telah mengikat janji, dapat memilih penyelesaian sengketa melalui beberapa forum penyelesaian sesuai dengan isi akad. Perbedaan pandangan semakin meruncing ketika penjelasan Pasal 55 ayat (2) UU Perbankan Syariah tersebut memberikan empat pilihan upaya penyelesaian yang dapat ditempuh para pihak, yakni musyawarah, mediasi perbankan, melalui Badan Arbitrase Syariah Nasional (Basyarnas) atau lembaga arbitrase lain, dan/atau melalui pengadilan dalam lingkungan Peradilan Umum.

Dengan kata lain, ketentuan ini di satu sisi telah menyatakan bahwa sengketa 
perbankan syariah adalah kewenangan dalam lingkungan peradilan agama, namun pada pasal berikutnya menyatakan, para pihak diberikan kebebasan memilih forum penyelesaian sengketa yang salah satunya adalah peradilan umum.

Dalam praktiknya, rumusan tersebut menimbulkan adanya ketidakpastian hukum, dimana seringkali menjadi pangkal masalah antara nasabah dengan pihak bank syariah.

\section{B. Perumusan masalah}

Adapun yang akan menjadi penekanan permasalahan dalam tulisan ini adalah faktor-faktor yang melatar belakangi lahirnya keputusan Mahkamah Konstitusi Nomor : 093/MK/2012 Tentang Perbankan Syariah dan Bagaimanakah Kompetensi Pengadilan Agama dalam penyelesaian sengketa Perbankan syariah pasca adanya Putusan Mahkamah Konstitusi

\section{Metode Penelitian}

Pendekatan masalah yang digunakan dalam tulisan ini adalah berbentuk penelitian yang bersifat kualitatif, adalah penelitian tentang riset yang bersifat deskriptif dan cenderung menggunakan analisis proses dan makna lebih ditonjolkan dalam penelitian kualitatif. Penelitian ini merupakan penelitian deskriptif kualitatif, maka penelitian ini menggunakan dua sumber data, yaitu data primer dan data skunder. Sumber data primer adalah sumber data yang langsung memberikan data kepada pengumpul data. Sedangkan sumber data sekunder merupakan sumber data yang tidak langsung memberikan data. Data yang di peroleh baik data primer dan data sekunder dianalisis secara deskriptif kualitatif.

\section{Pembahasan}

\section{Lembaga Peradilan Agama dan Kebutuhan Masyarakat}

Keberadaan lembaga Peradilan Agama di Indonesia tidak dapat dilepaskan dari kebutuhan masyarakat Indonesia yang beragama Islam dalam melaksanakan ajaran agamanya yang berupa hukum Islam. Secara yuridis Peradilan Agama sebagai salah satu pelaksana kekuasaan kehakiman di Indonesia telah diatur oleh konstitusi yakni dalam Pasal 24 Ayat (2) UUD NRI 1945 yang menyebutkan bahwa : “Kekuasaan kehakiman dilakukan oleh sebuah Mahkamah Agung dan badan peradilan yang berada 
di bawahnya dalam lingkungan Peradilan Umum, lingkungan Peradilan Agama, lingkungan Peradilan Militer, lingkungan Peradilan Tata Usaha Negara, dan oleh sebuah Mahkamah Konstitusi.”

Eksistensi lembaga Peradilan Agama sebagai salah satu pelaksana kekuasaan kehakiman di Indonesia mengalami pasang surut sejalan dengan situasi politik pemerintahan yang ada. Sebelumnya, berdasarkan ketentuan Pasal 49 Ayat (1) Undang Undang Nomor 7 Tahun 1989, kewenangan Peradilan Agama hanya terbatas pada penyelesaian sengketa di bidang perkawinan, kewarisan, wasiat, dan hibah yang dilakukan berdasarkan hukum Islam, serta wakaf dan shadaqoh.

Namun setelah dilakukannya amandemen, berdasarkan Undang - Undang Nomor 3 Tahun 2006 Tentang Perubahan Atas Undang - Undang Nomor 7 Tahun 1989 Tentang Peradilan Agama, Pengadilan Agama telah memiliki suatu kompetensi baru khususnya dalam menangani sengketa ekonomi syariah. Dalam Pasal 49 menyatakan bahwa, Pengadilan Agama bertugas dan berwenang memeriksa, memutus dan menyelesaikan perkara di tingkat pertama antara orang - orang yang beragama Islam di bidang perkawinan, waris, wasiat, hibah, wakaf, zakat, infaq, shadaqoh dan ekonomi syariah.

Dalam kehidupan suatu negara, perbankan merupakan salah satu agen pembangunan (agen of development). Hal ini dikarenakan fungsi utama dari perbankan itu sendiri sebagai lembaga yang menghimpun dana dari masyarakat dalam bentuk simpanan dan menyalurkannya kembali ke masyarakat dalam bentuk kredit atau pembiayaan. Fungsi inilah yang lazim disebut sebagai intermediasi keuangan (financial intermediary function). ${ }^{2}$ Selain itu, peranan yang sangat vital dari perbankan sebagai salah satu lembaga perekonomian, telah memberikan sumbangsih yang cukup besar tidak hanya pada pertumbuhan ekonomi negara tapi juga terhadap taraf kemakmuran rakyat. Upaya terus menerus yang dilakukan oleh semua pihak untuk melengkapi aturan hukum beroperasinya bank syariah pada akhirnya membuahkan hasil dengan disahkannya Undang - Undang Nomor 21 Tahun 2008 Tentang Perbankan Syariah pada tanggal 16 Juli 2008. Dengan adanya undang - undang tersebut, maka semakin mantaplah eksistensi bank syariah di Indonesia sebagai lembaga perantara keuangan berbasis syariah dan dalam menjalankan aktivitasnya dapat diterapkan secara optimal,

\footnotetext{
${ }^{2}$ Amiruddin K., Perbankan Syariah Dalam Perspektif Hukum, (Makassar: Al-Risalah Volume II, 2011), Hlm. 170.
} 
konkrit dan seutuhnya.

Lahirnya Undang - Undang Nomor 21 Tahun 2008 Tentang Perbankan Syariah kemudian diharapkan selain mampu membawa dampak positif pada eksistensi lembaga perbankan syariah di Indonesia tapi juga diharapakan dapat memperkuat legitimasi kewenangan baru Pengadilan Agama yakni dalam hal penyelesaian sengketa ekonomi syariah. Namun, pada kenyataannya harus diakui bahwa UU Perbankan Syariah justru malah membawa dampak negatif terhadap kewenangan Pengadilan Agama sebab, telah menimbulkan adanya tumpang tindih kewenangan antara Pengadilan Agama dan Pengadilan Negeri sehingga menimbulkan pula ketidakpastian hukum akibat adanya tumpang tindih kewenangan tersebut.

Setelah adanya putusan atas pengajuan uji materi (judicial review) atas penjelasan pasal 52 Ayat (2) dan (3) UU Nomor 21 tahun 2008 tentang Perbankan Syari'ah yang diajukan Dadang Achmad, maka Kompetensi Pengadilan Agama Terhitung tepat sejak tanggal 29 Agustus 2013, bahwa tidak ada lagi dualisme penyelesaian sengketa perkara perbankan syari’ah.3 Mahkamah Konstitusi melalui putusan nomor 93/PUU-X/2012 menegaskan bahwa penjelasan pasal 52 Ayat (2) UU Nomor 21 tahun 2008 tentang Perbankan Syari'ah bertentangan dengan UUD 1945 dan tidak memiliki kekuatan hukum mengikat. Penjelasan pasal tersebut lah yang selama ini menjadi biang kemunculan pilihan penyelesaian sengketa (choice of forum). Konsekuensi konstitusionalnya: sejak putusan tersebut dibacakan, Pengadilan Agama menjadi satu-satunya pengadilan yang berwenang mengadili perkara perbankan syari'ah. Menurut pertimbangan Mahkamah Konstitusi, penjelasan pasal tersebut menimbulkan ketidakpastian hukum dan hilangnya hak konstitusional nasabah untuk mendapatkan kepastian hukum yang adil dalam penyelesaian sengketa perbankan syariah (vide Pasal 28D ayat (1) UUD 1945) yang bertentangan dengan prinsip-prinsip konstitusi. Oleh karena itu, layak untuk dinyatakan tidak mempunyai kekuatan hukum mengikat.

Lahirnya putusan Mahkamah Konstitusi Nomor 93/PUU-X/2012 maka mengembalikan kewenangan mutlak Pengadilan Agama sebagai satu - satunya lembaga peradilan yang berwenang untuk memeriksa, memutus dan menyelesaikan sengketa di

\footnotetext{
${ }^{3}$ Pencantuman waktu selesainya pembacaan putusan tersebut termaktub dalam bagian penutup putusan Mahkamah Konstitusi Nomor 93/PUU-X/2012.
} 
bidang perbankan syariah secara litigasi yang sebelumnya juga menjadi kewenangan Peradilan Umum akibat dibukanya pilihan choice of forum ( penyelesaian sengketa perbankan syariah sebagaimana yang tertera dalam penjelasan Pasal 55 Ayat (2) UU Perbankan Syariah.

2. Berikut faktor -faktor yang melatar belakangi lahirnya putusan Mahkamah Konstitusi diantaranya yaitu:

a. Adanya pilihan forum (choice of forum) dalam penyelesaian sengketa perbankan syariah.

Pilihan forum (choise of forum) terkait penyelesaian sengketa perbankan syariah yang termuat dalam Pasal 55 UU Perbankan Syariahpada saat ini dipandang sebagai suatu anomali dalam tatanan hukum diIndonesia. Di satu sisi, choise of forum memberikan kebebasan dan kemudahan bagi para pihak yang bersengketa untuk memilih forumpenyelesaian sengketa. Namun, di sisi lain choise of forum juga memberikan efek negatif karena menimbulkan terjadinya tumpang tindih kewenangan antara Pengadilan Agama dan Pengadilan Negeri, dimana The last resort dari suatu penyelesaian sengketa adalah melalui lembaga peradilan. Hanya saja, selama ini muncul pertanyaan apakah Pengadilan Negeri atau Pengadilan Agama yang berkompeten dalampenyelesaian sengketa di bidang muamalah Islam. Sebab, sebelumnya sesuai dengan ketentuan Undang - Undang Nomor 2 Tahun 1986 Tentang Peradilan Umum sengketa dalam bidang perbankan syariah termasuk dalam ruang lingkup kewenangan absolute Peradilan Umum. Hanya saja, dalam hal ini persoalannya bukan hanya menyangkut hakim Peradilan Umum yang belum tentu menguasai masalah ekonomi syariah, ${ }^{4}$ tetapi lebih dari itu, Peradilan Umum tidak menggunakan syariah Islam sebagai landasan hukum dalam menyelesaikan perkara- perkara yang diajukan kepadanya. $^{5}$

b. Adanya multitafsir dalam memaknai Undang-Undang (choice of law)

Adanya multitafsir yang mungkin muncul karena tidak terpenuhinya kepentingan (keinginan) para pihak atau hasil dari penafsiran masing - masing pihak

\footnotetext{
${ }^{4}$ Karnaen Perwataatmadja, Bank dan Asuransi Islam Di Indonesia, (Jakarata:Prenada Media, 2005), Hlm. 295.

${ }^{5}$ Muh. Syafii Antonio, Bank Syariah Dari Teori Ke Praktek, (Jakarta: Gema Insani, 2005), Hlm. 214.
} 
terhadap ketentuan Pasal 55 Ayat (2) Undang - Undang Nomor 21 Tahun 2008 dan penjelasannya tersebut, yang kemudian persoalan hukum kemudian muncul apabila melihat ketentuan penyelesaian sengketa perbankan syariah sebagaimana yang tercantum dalam Pasal 55 Ayat (2) UU Perbankan Syariah. Sebab, peluang diselesaikannya sengketa perbankan syariah dalam lingkungan Peradilan Umum kembali terbuka. Sinkronisasi hukum kekuasaan kehakiman khususnya mengenai kewenangan Pengadilan Agama dalam menangani sengketa perbankan syariah sebagaimana diamanatkan dalam UU No. 3 Tahun 2006 kemudian dipertanyakan karena berimplikasi pada timbulnya sengketa kewenangan antar dua lembaga peradilan dalam hal penyelesaian sengketa dibidang perbankan syariah.

\section{c. Adanya kejadian conflict of dispute settlement (pertentangan mengenai lembaga penyelesaian sengketa.}

Dualisme penyelesaian sengketa perbankan syariah ini kemudian oleh beberapa kalangan tidak hanya dianggap sebatas persoalan sengketa kewenangan antara dua pranata sosial saja, tapi juga telah menimbulkan “ketidakpastian hukum” bagi para pihak yang bersengketa di dalamnya. Dan, hal ini tentunya bertentangan dengan amanah UUD NRI 1945 sebagaimana yang tertuang dalam Pasal 28D Ayat (1) yang secara tegas menyatakan bahwa : "setiap orang berhak atas pengakuan, jaminan, perlindungan, dan kepastian hukum yang adil serta perlakuan yang sama dihadapan hukum.”

\section{d. Adanya pengujian undang - undang (yudicial review)}

Mengingat salah satu kewenangan Mahkamah Konstitusi adalah untuk menguji suatu undang - undang terhadap UUD NRI 1945 maka diajukanlah permohonan untuk dilakukan pengujian undang - undang (yudicial review) terhadap Undang - Undang Nomor 21 Tahun 2008 Perbankan Syariah (Lembaran Negara Republik Indonesia Tahun 2008 Nomor 94) yakni Pasal 55 Ayat (2) dan (3) yang mengatur tentang penyelesaian sengketa dengan pokok permohonan bahwa Pasal 55 Ayat (2) dan (3) undang - undang tersebut telah menimbulkan ketidakpastian hukum. Setelah adanya putusan atas pengajuan uji materi (judicial review) atas penjelasan pasal 52 Ayat (2) dan (3) UU Nomor 21 tahun 2008 tentang Perbankan Syari’ah yang diajukan Dadang Achmad dan hasil pengujian ini kemudian dituangkan dalam amar putusan dengan Nomor 93/PUU-X/2012 Tentang Perbankan Syariah dan telah dibacakan pada tanggal 29 Agustus Tahun 2013. 
Pilihan forum (choise of forum) terkait penyelesaian sengketa perbankan syariah yang termuat dalam Pasal 55 UU Perbankan Syariah pada saat ini dipandang sebagai suatu anomali dalam tatanan hukum diIndonesia. Di satu sisi, choise of forum memberikan kebebasan dan kemudahan bagi para pihak yang bersengketa untuk memilih forum penyelesaian sengketa. Namun, di sisi lain choise of forum juga memberikan efek negatif karena menimbulkan terjadinya tumpang tindih kewenangan antara Pengadilan Agama dan Pengadilan Negeri. Selain itu, Pasal 55 UU Perbankan Syariah nyatanya tidak hanyadipandang telah menimbulkan dualisme kewenangan antara dua pranata sosial saja, tapi lebih jauh lagi pasal tersebut pun juga tidak memberikan kepastian hukum bagi para pihak yang bersengketa di dalamnyasebagaimana yang telah di amanahkan oleh UUD NRI 1945. Hal ini tentusaja merupakan suatu kerugian, mengingat begitu banyaknya masyarakat yang melakukan transaksi di bidang perbankan syariah sehingga, peluang terjadinya sengketa pun semakin besar.

Kepastian merupakan ciri yang tidak dapat dipisahkan dari hukum, terutama untuk norma hukum tertulis. Hukum tanpa nilai kepastian akan kehilangan makna karena tidak dapat lagi digunakan sebagai pedoman perilaku bagi setiap orang. Kepastian sendiri disebut sebagai salah satu tujuan dari hukum.

Kepastian hukum adalah bagian dan dibutuhkan sebagai upaya menegakkan keadilan. Dengan kepastian hukum setiap perbuatan yang terjadi dalam kondisi yang sama akan mendapatkan sanksi. Adapun kemanfaatan dilekatkan pada hukum sebagai alat untuk mengarahkan masyarakat yang tentu saja tidak boleh melanggar keadilan.

Dalam praktek penegakan hukum yang sedang berlangsung saat ini, pengutamaan nilai kepastian hukum lebih menonjol dibanding dengan rasa keadilan dan kemanfaatannya. Dengan demikian apabila hukum lebih mengutamakan kepastian hukum maka dengan sendirinya penegakannya akan menggeser nilai-nilai keadilan dan kemanfaatan hukum demikian pula sebaliknya. Sehingga dalam penerapannya banyak terjadi permasalahan-permasalahan yang berkaitan dengan masalah penegakan hukum dimana masyarakat merasa kecewa dengan adanya suatu putusan hakim yang dinilai mencederai rasa keadilan masyarakat dan hanya mementingkan penegakan hukum secara prosedural semata. Oleh karena itu pentingnya memahami hakikat tujuan hukum yaitu keadilan, kepastian dan kemanfaatan dalam rangka penegakkan hukum untuk mewujudkan rasa keadilan dengan adanya jaminan kepastian hukum dan memberikan 
manfaat bagi masyarakat sehingga kepercayaan masyarakat terhadap hukum dapat tetap terjaga dalam menjaga ketertiban di masyarakat.

Kepastian hukum menghendaki adanya upaya pengaturan hukum dalam perundang-undangan yang dibuat oleh pihak yang berwenang dan berwibawa, sehingga aturan-aturan itu memiliki aspek yuridis yang dapat menjamin adanya kepastian bahwa hukum berfungsi sebagai suatu peraturan yang harus ditaati.

Dengan demikian, ada beberapa ketentuan yang dapat dipahami terkait dampak atau akibat hukum dari putusan Mahkamah Konstitusi tersebut; Pertama, putusan Mahkamah Konstitusi di atas menghapuskan kewenangan Peradilan Umum dalam hal penyelesaian sengketa perbankan syariah serta, menjadikan Pengadilan Agama sebagai satu - satunya institusi peradilan yang berwenang dalam hal memeriksa, memutus, dan menyelesaikan sengketa perbankan syariah secara litigasi. Kedua, putusan Mahkamah Konstitusi mengakibatkan secara yuridis bahwa semua "pembatasan" pilihan forum (choice of forum) penyelesaian sengketa yang tertera dalam penjelasan Pasal 55 Ayat (2) tidak mempunyai kekuatan hukum mengikat, baik penyelesaian secara litigasi maupun non litigasi. Ketiga, segala ketentuan dari penyelesaian sengketa ekonomi syariah harus kembali kepada pasal induk yaitu Pasal 55 Ayat (1), (2), dan (3) sehingga choice of forum tetap berlaku. ${ }^{6}$

Terkait pilihan forum non litigasi dari penyelesaian sengketa perbankan syariah diatas terdapat beberapa catatan yang perlu di ketahui yakni, penyelesaian sengketa secara non litigasi tetap dibenarkan selama tidak bertentangan dengan prinsip - prinsip syariah sebagaimana yangdijelaskan dalam Pasal 55 Ayat (3) UU Perbankan Syariah. Apabila parapihak tidak sepakat untuk menyelesaikan sengketa di Pengadilan Agama dan lebih memilih pilihan forum sebagai second choise, maka diwajibkankepada para pihak untuk membuat kesepakatan tertulis dan di dalam akta kesepakatan tersebut lengkap termuat mengenai hak dan kewajibanmasing - masing pihak.

Selain itu, dengan dihapuskannya penjelasan Pasal 55 Ayat (2)Undang - Undang Nomor 21 Tahun 2008 tentang Perbankan Syariah,maka para pihak tidak lagi terpaku dalam menyelesaikan sengketanya secara non litigasi pada musyawarah, mediasi perbankan, arbitrase melalui Badan Arbitrase Syariah Nasional atau lembaga arbitrase

\footnotetext{
${ }^{6}$ Abdurrahman Rahim, loc cit., Hlm. 15
} 
lainnya,tetapi dapat juga menempuh proses non litigasi lainnya seperti konsultasi,negosiasi (perundingan), konsiliasi, mediasi non mediasi perbankan,pendapat atau penilaian ahli. ${ }^{7}$ Selain berimplikasi terhadap lembaga yang berwenang dalampenyelesaian sengketa perbankan syariah baik secara litigasi maupun nonlitigasi sebagaimana yang telah dipaparkan di atas. Terdapat pula implikasi hukum lain yang ditimbulkan oleh putusan Mahkamah Konstitusi tersebut, yakni terhadap perjanjian (akad) yang memuat klausula penyelesaian sengketa perbankan syariah di Pengadilan Negeri baik yangdibuat sebelum maupun setelah keluarnya putusan Mahkamah Konstitusi.

Maka dengan Terbitnya putusan Mahkamah Konstitusi Nomor 93/PUU-X/2012 Konsekuensi konstitusionalnya: sejak putusan tersebut dibacakan, Pengadilan Agama menjadi satu-satunya pengadilan yang berwenang mengadili perkara perbankan syari’ah. Eksistensi kompetensi Pengadilan Agama dalam menyelesaikan sengketa perbankan syariah semakin absolut dan juga adanya jaminan kepastian hukum dimana tidak lagi adanya dualisme kewenangan dalam penyelesaian sengeketa perbankan syariah seperti sebelum adanya putusan Mahkamah Konstitusi, sehingga kepastian hukum itu sendiri dapat mengandung beberapa arti, yakni adanya kejelasan, tidak menimbulkan multitafsir, tidak menimbulkan kontradiktif, dan dapat dilaksanakan dimana hukum harus berlaku tegas di dalam masyarakat, mengandung keterbukaan sehingga siapapun dapat memahami makna atas suatu ketentuan hukum karena hukum yang satu dengan yang lain tidak boleh kontradiktif sehingga tidak menjadi sumber keraguan. Dengan adanya putusan Mahkamah Konstitusi nomor 93/PUU-X/2012 mengakhiri adanya dualisme hukum yang berujung terciptanya suatu kepastian hukum.

\section{E. Kesimpulan}

Adapun kesimpulan yang dapat ditarik dari pembahasan kasus di atas adalah sebagai berikut: Pertama, kompetensi Pengadilan Agama yang diterapkan dalam penyelesaian sengketa perbankan syariah khususnya pasca adanya putusan Mahkamah

\footnotetext{
${ }^{7}$ Abdul Mannan, Penyelesaian Sengketa Ekonomi Syariah, Sebuah Kewenangan Baru peradilan Agama, dalam mimbar Hukum Edisi 73 Tahun 2011, Pusat Hukum Islam dan Masyarakat Madani (PPHIMM), Hlm. 20 - 35.
} 
Konstitusi Nomor. 93/PUU-X/2014 sudah dilaksanakan dengan baik sesuai dengan kewenangannya dalam menangani perkara sengketa perbankan syariah. Kedua, dengan terbitnya putusan Mahkamah Konstitusi Nomor 93/PUU-X/2012 yang menyatakan penjelasan Pasal 55 ayat (2) Undang-Undang Nomor 21 Tahun 2008 tentang Perbankan Syariah, maka tidak ada lagi dualisme penyelesaian sengketa perbankan syariah dan hal tersebut sesuai dengan amanah UUD NRI 1945 sebagaimana yang tertuang dalam Pasal 28D Ayat (1) yang secara tegas menyatakan bahwa : "setiap orang berhak atas pengakuan, jaminan, perlindungan, dan kepastian hukum yang adil serta perlakuan yang sama dihadapan hukum.”

\section{F. Saran}

Pertama, bahwa Pengadilan Agama dengan kompetensinya yang mutlak untuk dapat meyelesaikan permasalahan mengenai sengketa ekonomi syariah khususnya perbankan syariah, dan diharapkan mampu untuk mengemban tugas dan tanggung jawab terhadap perkara tersebut. Kedua, sumber daya manusianya harus disiapkan dan ditingkatkan untuk lebih profesional di bidangnya, terutama para Hakimnya untuk mendalami tentang perkara yang berkaitan dengan ekonomi syariah (perbankan syariah), dengan memperbanyak pendidikan dan pelatihan khusus bagi para hakim agar dapat mendalami permasalahan ekonomi syariah (perbankan syariah). Selain itu payung hukum yang kuat sangat diperlukan agar masyarakat pencari keadilan merasa terlindungi dari ketidakpastian hukum. Ketiga bagi pemangku kebijakan dalam hal ini pemerintah agar kedepannya tidak lagi mengeluarkan atau membuat regulasi yang menimbulkan adanya multitafsir, tumpang tindih antara peraturan yang satu dengan yang lainnya sehingga menimbulkan adanya ketidakpastian hukum yang pada akhirnya tidak terwujudnya rasa keadilan yang merupakan cita-cita hukum itu sendiri 


\section{Daftar Pustaka}

Amiruddin K., Perbankan Syariah Dalam Perspektif Hukum, (Makassar: Al- Risalah Volume II, 2011)

Karnaen Perwataatmadja, Bank dan Asuransi Islam Di Indonesia, (Jakarata:Prenada Media, 2005)

Muh. Syafii Antonio, Bank Syariah Dari Teori Ke Praktek, (Jakarta: Gema Insani,2005)

Abdul Mannan, Penyelesaian Sengketa Ekonomi Syariah, Sebuah Kewenangan Baru peradilan Agama, dalam mimbar Hukum Edisi 73 Tahun 2011, Pusat Hukum Islam dan Masyarakat Madani (PPHIMM), Hlm. 20 - 35. 